Rozprawy Komisji Językowej ŁTN, t. LXV, 2018

ISSN 0076-0390; e-ISSN 2450-9310

https://doi.org/10.26485/RKJ/2018/65/5

Ewelina Lechocka*

\title{
ZNACZENIE I FUNKCJA MOTYWU KALINY W WARMIŃSKO-MAZURSKICH PIEŚNIACH LUDOWYCH
}

\author{
MEANING AND FUNCTION OF VIBURNUM MOTIVES \\ IN FOLK SONGS FROM WARMIA AND MASURIA
}

Viburnum has been present in folk songs very often as an element of natural landscape but men also take advantage of it for its practical usage. It is being considered as a spot for human and animal activities. The contexts expose such its features as: small size, redness of the fruits, width of the leaves or its slenderness. Moreover, folk songs use the name of the plant for its symbolic meaning which realizes ingrained-in-folk-tradition picture of a viburnum - a symbol of femininity.

Keywords: viburnum, meaning of viburnum motives, function of viburnum motives, Warmia, Masuria, folk songs

Słowa kluczowe: kalina, znaczenie motywu kaliny, funkcja motywu kaliny, Warmia, Mazury, pieśni ludowe

\section{KALINA - INFORMACJA ETNOGRAFICZNA}

Kalina, Viburnum, jest rośliną z rodziny przewiertniowatych, obejmującej około dwustu gatunków rosnących w rejonach umiarkowanych i tropikalnych. W Polsce występują dziko tylko dwa krzewy: kalina koralowa (Viburnum opulus) i kalina hordowina (Viburnum lantana) [Czikow, Łaptiew, 1992, s. 143]. Pierwsza z nich rośnie najczęściej na wilgotnych glebach, nad zbiornikami wodnymi, w które obfitują Warmia i Mazury i zapewne dlatego na tych terenach należy do bardziej popularnych krzewów [Zientara-Malewska, 1959, s. 10, 12].

* Katedra Slawistyki, Wydział Filologiczny Uniwersytetu Gdańskiego, ul. Wita Stwosza 51, 80-308 Gdańsk; e-mail: ewelinalechocka@wp.pl. 
Kalina stanowi, w okresie kwitnienia i owocowania, a także z uwagi na jesienne kolory liści, ozdobę leśnego podszycia. Doceniona została jednak nie tylko ze względu na swój atrakcyjny wygląd, ale i z powodu właściwości leczniczych ${ }^{1}$.

Pierwsze wzmianki o leczniczym zastosowaniu kaliny znajdują się już w szesnastowiecznych zielnikach. Od najdawniejszych czasów owoce kaliny zalecano jako lek ogólnie wzmacniający i poprawiający akcję serca. W polskiej medycynie ludowej kalina posiadała szerokie zastosowanie w przypadku dolegliwości układu oddechowego i krwionośnego².

Picie soku z owoców zebranych jesienią łagodziło kaszel, a napar z liści i jagód kalinowych działał kojąco przy zapaleniu gardła. Kwaśne owoce kaliny, przypominające wyglądem porzeczki, zawierają bowiem dużo pektyn, cukry, kwasy organiczne, garbniki, karoten, a przede wszystkim witaminę C, której jest tu więcej niż w owocach cytrusowych [Rumińska, Ożarowski, 1990, s. 197].

Jagody można spożywać w stanie surowym lub w postaci kompotu, kisielu, galaretki, marmolady, nalewki bądź nadzienia do pierogów. Herbata z owoców kaliny jest nie tylko smaczna, ale działa również wzmacniająco i uspokajająco oraz łagodzi bóle głowy.

Ponadto kalina koralowa to roślina miododajna, a sok z jej owoców może służyć jako naturalny barwnik do wielu produktów żywnościowych. Odwar z korzeni jest środkiem przeciw skazie limfatycznej, drgawkom, histerii, bezsenności $\mathrm{i}$ astmie. Odwar $\mathrm{z}$ kwiatów poprawia trawienie i zalecany bywa w bolesnych skurczach jelit oraz biegunce, a także jako środek wykrztuśny, napotny i wskazany w niektórych chorobach kobiecych. Korę kaliny, zebraną wczesną wiosna, wysuszoną i zmieloną na proszek, stosowano jako środek tamujący krwawienia oraz lek przeciwskurczowy w bolesnym miesiączkowaniu. Natomiast wywarem z kory krzewu smarowano łysiejące głowy w nadziei na odzyskanie owłosienia [Czikow, Łaptiew, 1992, s. 143].

Jednocześnie spożywanie przetworów z kaliny koralowej w nadmiernych ilościach mogło powodować niepożądane skutki: wymioty, zawroty głowy, zaburzenia mowy, zaburzenia ruchowe oraz utratę przytomności. Roślina ta może

1 W medycynie oficjalnej kalina stosowana jest w zaburzeniach klimakteryjnych, działa przeciwskurczowo i przeciwkrwotocznie na narządy rodne, jest także jednym ze składników czopków przeciw hemoroidom. Najczęściej jednak wykorzystuje się ją w homeopatii - w zaburzeniach miesiączkowania i w przypadku zagrożenia poronieniem [Rumińska, Ożarowski, 1990, s. 197].

2 Kalina podawana była powszechnie przy dusznościach i astmie [Niebrzegowska, 2000, s. 133]. Sok lub odwar z jej owoców z dodatkiem miodu uważano za skuteczny środek na biegunkę, chorobę wrzodową żołądka i dwunastnicy, zapalenie okrężnicy, żylaki odbytu, krwawienia wewnętrzne i krwotoki z nosa, a jagody utarte z cukrem podawano cierpiącym na nadciśnienie [Robotycki, Babik, 2005, s. 61]. 
być również trująca dla bydła i koni, choć odwary z kory stosowane bywają przez weterynarzy w leczeniu chorób narządów oddechowych zwierząt [Bagiński, Mowszowicz, 1963, s. 236-237].

W tradycyjnej kulturze Słowian kalina uważana była za krzew żeński, symbol szczęścia, dziewczęcego piękna i miłości, konotujący życiodajne siły i płodność (sprzyjała temu najwyraźniej czerwona barwa jej owoców) [Ziółkowska, 1983, s. 150]. Na wschodzie Słowiańszczyzny kalinę uważano za drzewo weselne, wykorzystując ją szeroko w obrzędach i ozdabiając nią korowaj, potrawy i wianki. Pestka owocu, przypominająca swoim kształtem serce, stanowiła na Ukrainie znak męstwa ludzi, którzy oddali życie w walce z wrogami [Szcześniak, 2015, s. $163-165]^{3}$. Na Białorusi natomiast kalina, ze względu na swoją trójbarwność (białe kwiaty, czerwone owoce, czarna kora), wchodziła w skład przestrzeni sakralnej - mocno wiązano ją ze światem zmarłych, nazywając drzewem nieszczęśliwym (jest ono niskie, rośnie krótko i ma gorzkie owoce). Kalinę sadzono często na grobach, które omiatano jej gałązkami, co jest konsekwencją łączenia krzewu z symbolem przejścia ze świata żywych do świata zmarłych [Szcześniak, 2013, s. 194-195] ${ }^{4}$. O ważnej pozycji, jaką zajmował ów krzew w kulturze ludowej, świadczy ponadto zwyczaj święcenia gałązek kaliny w dniu Matki Boskiej Zielnej. W Małopolsce wplatano w wieniec dożynkowy korale kalinowe, a gałązki kaliny z owocami wchodziły w skład bukietów święconych podczas Święta Wniebowzięcie Najświętszej Maryi Panny [Trąba, Wolański, Rogut, 2014, s. 89]. Kalinę uważano powszechnie za skuteczną ochronę przeciwko złym mocom i dlatego sadzono ją chętnie na granicach pól i posesji, a w niektórych krajach słowiańskich jej gałązkami przybierano domy w dni uważane za czas nasilonego działania demonów i czarownic [Ziółkowska, 1983, s. 136] .

3 Znana ukraińska legenda mówi o tym, jak młode, niezamężne dziewczęta wyprowadziły na nieprzebyte bagna oddziały tatarsko-mongolskich napastników i ginąc wraz z nimi, zamieniły się w okryte białym kwieciem krzewy, które jesienią zdobią czerwone, koralowe jagody. Kaliny miały zatem powstać z krwi odważnych dziewcząt [Szcześniak, 2015, s. 155-156].

${ }_{4} \mathrm{Na}$ Podlasiu kalinę sadzono na grobach młodych dziewcząt i chłopców, wierząc, że złamanie takiego krzewu albo wykopanie go jest zbrodnią, która zostanie ukarana. Nawet wąchanie kalinowych kwiatów na cmentarzu było niebezpieczne, groziło bowiem utratą zmysłu powonienia. Na Kujawach krzew kojarzono ze smutkiem i cierpieniem, dziewictwem i skromnością. Wierzono, że gdy dziewczyna umiera przed ślubem, zamienia się w kalinę [Szcześniak, 2013, s. 194-195].

5 Szerszych informacji na temat znaczenia kaliny z literaturze, kulturze i zwyczajach słowiańskich dostarcza publikacja Krystyny Szcześniak Kalina oczyma slawisty etnolingwisty [Szcześniak, 2015, s. 155-166]. 


\section{FREKWENCJA I ZNACZENIE MOTYWU KALINY W PIEŚNIACH LUDOWYCH}

Materiał językowy zebrany dla potrzeb niniejszej analizy wyekscerpowany został z dziesięciu antologii pieśni ludowych z terenu Warmii i Mazur. Są wśród nich zarówno zbiory dziewiętnastowieczne, takie jak: Pieśni ludu znad górnej Drwęcy Gustawa Gizewiusza [2000], Stoi lipa, lipuleczka Józefa Gąsiorowskiego [1976], O Mazurach Wojciecha Kętrzyńskiego [1988] oraz Mazury Pruskie Oskara Kolberga [1966], jak i pieśni zebrane na początku XX wieku przez Augusta Steffena w książce Zbiór polskich pieśni ludowych z Warmji [Steffen, 1931] oraz antologie powstałe po II wojnie światowej, autorstwa Władysława Gębika [1952], Mariana Sobieskiego [1955], Marii Okęckiej-Bromkowej [1966], Tadeusza Orackiego [1957], a także pięciotomowe dzieło Barbary Krzyżaniak i Aleksandra Pawlaka [2002].

W obrębie przyjętej próby materiałowej wyraz kalina i jego derywaty pojawiają się 137 razy, w 33 różnych kontekstach (Krzyżaniak, Pawlak: 58 razy, Gizewiusz: 27, Kolberg: 21, Okęcka-Bromkowa: 13, Gąsiorowski: 6, Kętrzyński: 4, Steffen: 3, Oracki: 3, Gębik: 1, Sobieski: 1). Rozbieżność ta wynika $\mathrm{z}$ obecności analizowanego wyrazu w refrenach utworów oraz z zamieszczania w zbiorach wielu wariantów jednej pieśni. Motyw kaliny funkcjonuje przy tym w różnorodnych typach tekstów ludowych, zarówno w pieśniach balladowych, popularnych, towarzyszących zabawom, zalotnych i miłosnych, jak i żołnierskich oraz historycznych. Wyraz ten nie został wykorzystany jedynie w pieśniach obrzędowych (dorocznych i weselnych), natomiast frekwencja występowania fitonimu w pozostałych gatunkach utworów ludowych nie wykazuje wyraźnej tendencji, która mogłaby wskazać na szczególną popularność analizowanego motyw w danym rodzaju pieśni folklorystycznych.

Wyrazy należące do rodziny słowotwórczej kalina pojawiają się w pieśniach ludowych wyłącznie w znaczeniu ogólnopolskim jako „Viburnum, krzew z rodziny przewiertniowatych (Caprifoliaceae), o kwiatach białych, owocach czerwonych; rośnie w strefie umiarkowanej półkuli północnej" [Doroszewski, 1964, s. 479]. Wśród leksemów należących do badanej rodziny wyrazów dominuje nazwa podstawowa: kalina, którą wykorzystywano wyłącznie w formie ogólnopolskiej (67 razy). Oprócz niej teksty folklorystyczne notują dwa leksemy derywowane oraz ich gwarowe warianty fonetyczne ${ }^{6}$. Zdecydowaną większość stanowi rzeczownik o charakterze deminutywnym kalinka (41) wraz z formą

6 Stanisław Dubisz notuje wyłącznie dwie formy, którymi posługują się mieszkańcy Warmii i Mazur dla określenia rośliny - nazwę kalina i deminutivum kalinka [Dubisz, 1977, s. 50-51]. 
gwarową kälinka (2), w której zaznaczono typową dla Mazurów artykulację $a$ jasnego ${ }^{7}$. Ponadto pojawiają się dwa derywowane przymiotniki: kalinowy (26) i kalinkowy (2). Pierwszy z nich oprócz postaci ogólnopolskiej zapisany został również w nietypowej formie z udźwięcznieniem głoski $k$ oraz wymianą spółgłoski $n$ na l: galilowy ${ }^{8}$. Określenie kalinkowy, będące derywatem przymiotnikowym utworzonym od zdrobniałej formy kalinka, pojawia się dwukrotnie, raz z uwzględnieniem mazurskiej wymowy a jasnego: kälinkowy. Wszystkie użyte przymiotniki określają rodzaj lasu, podobnie jak leksem kialinoski, który zanotowano z typowym na wschodzie zmiękczeniem głoski $k$ przed $a$ oraz $\mathrm{z}$ uproszczeniem grupy spółgłoskowej -wsk- do -sk- ${ }^{9}$.

Motyw kaliny odnosi się nie tylko do właściwego znaczenia tej rośliny, jakim jest nazwa gatunku krzewu, ale, na co warto zwrócić uwagę, wśród użytych w tekstach leksemów następują także przesunięcia metonimiczne znaczeń ${ }^{10}$. Oprócz znaczenia czysto roślinnego, dotyczącego leksemów nazywających całą roślinę (zwłaszcza rosnąca), analizowanego wyrazu użyto w znaczeniu partytywnym, dla określenia części rośliny, jaką jest owoc (lub rzadziej gałąź). Przeniesienie znaczenia z całości obiektu na jego część jest zgodne z drugą definicją kaliny,

${ }^{7}$ We wskazanym leksemie zaznaczono zjawisko przesunięcia ku przodowi i zwężenia artykulacji $a$ jasnego, realizowanego jako dźwięk między $a$ i $e$ (lub zupełnie $e$ ), które jest typowe dla północno-wschodnich Mazur. Zapis głoski w postaci $\ddot{a}$ wprowadzał w pieśniach Wojciech Kętrzyński, a powielił go Oskar Kolberg [1966, s. 23].

8 Jest to niezwykle interesujące zjawisko, ponieważ na Warmii, Mazurach i w Ostródzkiem występuje fonetyka międzywyrazowa ubezdźwięczniająca. Jednakże - jak podaje Maria Biolik - w niektórych warmińskich wyrazach gwarowych proces upodobnień postępowych jest martwy i wtedy dźwięczna lub bezdźwięczna wymowa jest na stałe przypisana do wyrazu i wszystkich jego form morfologicznych. Ponadto, jak zauważyła również M. Biolik [2014, s. 116-120], wymowa spółgłosek dźwięcznych i bezdźwięcznych ma często charakter indywidualny. Podobnie nietypowa - bo nienotowana przez opracowania gwaroznawców - jest wymiana zbliżonej artykulacyjnie głoski $n$ na $l$.

${ }^{9}$ Artykulacja spółgłoski $k$ przed $a \leq$ stp. $\check{a}$ dzieli teren na dwie części, a granica takiej wymowy przebiega zgodnie z zachodnią granicą powiatów mrągowskiego i piskiego. W części wschodniej dominuje w tej pozycji palatalna wymowa przytaczanych spółgłosek $(\hat{k} a)$, w części zachodniej niepalatalna ( $k a$ ) [Basara, 1987, s. 24-31; Wełpa, 2014, s. 11-14]. Natomiast upraszczanie grup spółgłoskowych jest właściwe dla całego regionu ostródzkiego, Warmii i Mazur.

${ }^{10}$ Dokonując analizy semantycznej motywu kaliny, wykorzystałam klasyfikację leksyki botanicznej zaproponowaną przez Ewę Rogowską-Cybulską w pracy pt. Gwarowy obraz roślin w świetle aktywności nominacyjnej ich nazw (na podstawie gwary wsi Wagi w powiecie łomżyńskim). Na podstawie tekstowych modyfikacji znaczeń i relacji zachodzących między polisemią a monosemią autorka wyróżnia przesunięcia metonimiczne, wśród których wymienia cztery grupy znaczeń, w jakich mogą występować motywy botaniczne. Są nimi znaczenia czysto roślinne, partytywne, botaniczne i rezultatywne [Rogowska-Cybulska, 2005, s. 83-122]. 
która może nazywać również 'owoc tego krzewu' [Doroszewski, 1964, s. 479]. Ponadto omawiany tu fitonim kilkakrotnie wykorzystano w znaczeniu genetycznym, jako nazwę surowca roślinnego. Przesunięcie znaczeniowe z określenia gatunku rośliny na materiał z niej uzyskiwany dotyczy w pieśniach kontekstów, w których kalina oznacza tworzywo, z którego wykonany został dany przedmiot.

Znaczenie czysto roślinne, które wykazuje zdecydowaną przewagę wśród występujących w analizowanych tekstach fitonimów, dotyczy aż 129 nazw, co stanowi ponad 94\% wszystkich użyć. Kalina jako cała roślina rosnąca przedstawiana bywa w pieśniach najczęściej w kontekście występowania w sąsiedztwie jaworu, np.: Kalina z jeworem rozstać sie nie może [Gębik, 1952, s. 84]; w pobliżu młyna, np.: Tam koło myna rośnie kalina [Krzyżaniak, Pawlak, 2002, V, s. 140] lub samotnie, np.: |: a tu kalina, biydna ptaszyna, samotna stoji, lato wspomina:|. [Krzyżaniak, Pawlak, 2002, V, s. 140], bądź w bliżej nieokreślonym miejscu, we wgłębieniu terenu, np.: Czemu, kalinko, w dole stoisz? [Okęcka-Bromkowa, 1966, s. 41]. Fitonim w znaczeniu czysto roślinnym wykorzystany został w utworach, w których kalina się buja, chwieje, giba, np. Stójże, kalinko, nie bujaj się, a ty, me dziewczę, rozmyślaj się [Kolberg, 1966, s. 515]. Ważnym elementem kaliny, która rośnie, sa jej liście - często eksponowane w tekstach folklorystycznych jako obiekt występujący na znacznej wysokości, np.: Wysoko, daleko listek na kalinie [Kolberg, 1966, s. 274], którego główną cechą jest szerokość, np.: Przy dolinie wódka ptynie, szeroki list na kalinie [Oracki, 1957, s. 224]. Na kalinie mogą kwitnąć kwiaty, np.: A na kalince śliczne kwiecie [Krzyżaniak, Pawlak, 2002, II, s. 63] oraz dojrzewać owoce, np.: Lubiem kaliny krasne jagódki [Krzyżaniak, Pawlak, 2002, V, s. 140]. Pod drzewem natomiast rosną niekiedy grzyby, np.: Kalina, kalina, pod kalina grzybki [Okęcka-Bromkowa, 1966, s. 324]. W innym przykładzie kalina jako całość stanowi element wyrażenia pójść w kaliny, czyli udać się do miejsca, w którym występują rośliny omawianego gatunku: Poszły panny w kaliny [Gizewiusz, 2000, s. 118]. Użycie badanego leksemu w znaczeniu całej rośliny odnosi się ponadto do wszystkich użyć derywatu przymiotnikowego kalinowy, który w każdym kontekście określa rodzaj lasu, np. Zija zionki, Jasieczku, w kalinowym laseczku [Steffen, 1931, s. 49]. Przymiotnik utworzony od wyrazu podstawowego kalina $\mathrm{w}$ znaczeniu czysto roślinnym wskazuje zatem na przewagę danego gatunku rośliny w skupisku leśnym. Znaczenie czysto roślinne dotyczy ponadto wszystkich kontekstów, w których użycie leksemu pełni rolę zabiegu stylistycznego, jak ma to miejsce we fragmencie: Siytym kóni Jasio mniat, | wszystkie siytym obsiodłat, kalina, kalina, kalina moja, | wszystkie siytym obsiodłat [Krzyżaniak, Pawlak, 2002, II, s. 219], w którym wyraz kalina jest wyłącznie nazwą gatunku drzewa. Niejednoznaczne wydają się natomiast 
przykłady, w których kalina kwitnie lub rozwija się, na przykład: Kalina zakście pięknie w ogrodzie [Kolberg, 1966, s. 554] oraz |:Ślicna kalinko, rozwijoj sie:| [Krzyżaniak, Pawlak, 2002, II, s. 64]. Proces kwitnięcia, podobnie jak czasownik rozwijać, może bowiem dotyczyć zarówno części, jak i całości obiektu ${ }^{11}$, niemniej ze względu na brak jednoznacznego wskazania świadczącego o przesunięciu metonimicznym uznaję i w tym przypadku znaczenie czysto roślinne fitonimu.

Motyw kaliny w znaczeniu partytywnym wykorzystany został natomiast w warmińsko-mazurskich pieśniach ludowych zaledwie sześć razy, co stanowi niewiele ponad $4 \%$ wszystkich użyć fitonimu. Najczęściej w tym przypadku kalina odnosi się do nazwy owocu jako elementu rośliny, który ze względu na czerwoną barwę może pozostawić zabrudzenia przypominające ślady krwi: Na jej carnej brwi nibi kropla krwi; kto wji, z jakij to przicyny, od maliny lub kaliny. Moze to nie krew? [Gąsiorowski, 1976, s. 29]. Inną częścią rośliny określaną mianem kaliny są gałęzie, które łamie bohaterka pieśni: Na tej górze mogiła, stojała tam dziewczyna; ćwierć kaliny tamała, na kozaka kiwała [Kolberg, 1966, s. 556].

Pozostałe dwa konteksty wykorzystują nazwę gatunku rośliny w znaczeniu genetycznym. W tych przypadkach kalina jest nazwą drewna - surowca, z którego został zbudowany most: Ej, uginaj się, ej, uchylaj się, kalinowy moście [Okęcka-Bromkowa, 1966, s. 42], lub określa tworzywo, z którego wykonano wieniec: Siedzi jescur $w$ toncu, | w kalinowym wioncu [Krzyżaniak, Pawlak, 2002, IV, s. 233].

\section{FUNKCJONOWANIE MOTYWU KALINY W PIEŚNIACH LUDOWYCH}

Dokonując analizy funkcjonowania motywu kaliny w pieśniach ludowych, posłużyłam się klasyfikacją zaproponowaną przez Andrzeja Stoffa, uznając ją za najbardziej odpowiednią w stosunku do specyfiki badanego materiału ${ }^{12}$.

${ }^{11}$ Czasownik kwitnąć na podstawie definicji słownikowej oznacza 'rozwijać się z pączka w kwiat; mieć kwiaty, okrywać się kwiatami', proces ten dotyczy zatem całej rośliny bądź jej części [Doroszewski, 1964, s. 1359], podobnie jak czasownik rozwijać się, który w odniesieniu do roślin oznacza tyle co: 'wypuścić liście, kwiaty; też o kwiatach, liściach, pączkach: rozchylić się' [Drabik, Sobol, 2007, s. 243].

${ }^{12} \mathrm{~W}$ artykule Problematyka teoretyczna funkcjonowania motywów roślinnych $w$ utworach literackich badacz, wychodząc z założenia, iż występowanie w tekście elementów flory nie jest obligatoryjne, lecz wynika wyłącznie z decyzji i zamierzeń autora (co w konsekwencji oznacza celowość ich wykorzystania oraz zrelatywizowanie motywów botanicznych względem człowieka), stworzył klasyfikację motywów roślinnych, wyróżniając sześć głównych funkcji, w jakich występują one w utworach literackich. Są to: funkcja metaforyczna, dekoracyjna, mimetyczna, przedmiotowa, ekspresywna i symboliczna. Pierwsza z nich - metaforyczna - jest zasadniczo odmienna od pozostałych, a jej cechą różnicująca jest brak przedmiotowego odpowiednika motywu w tekście. 
Ponadto analiza słownictwa botanicznego i dostrzeżenie pewnych osobliwości w posługiwaniu się $\mathrm{w}$ pieśniach tą leksyką spowodowało, że oprócz próby przyporządkowania motywów roślinnych kategoriom wprowadzonym przez badacza wyodrębniłam samodzielnie funkcje odmienne, tworząc kolejne podziały wewnątrz już istniejących. W obrębie funkcji mimetycznej wyróżniłam dwie podgrupy: funkcję mimetyczną właściwą i relacyjną. Funkcja mimetyczna właściwa wykorzystywana jest w sytuacjach, gdy kalina, będąc częścią świata przedstawionego, stoi w jego centrum, porastając określną przestrzeń i podlegając stanom i procesom właściwym roślinie. Natomiast funkcja mimetyczna relacyjna obejmuje wszystkie te konteksty, w których kalina stoi w relacji wobec bohaterów pieśni, stanowiąc miejsce działań ludzi bądź zwierząt.

Wszystkie funkcje, w jakich występuje wyraz kalina, wiążą się z przedmiotowym osadzeniem motywu w świecie przedstawionym tekstów ludowych. Najwyższą frekwencją wyróżnia się wśród nich funkcja mimetyczna właściwa ${ }^{13}$, która

Nazwa rośliny istnieje poza światem przedstawionym, stanowi jedynie językowy opis kreowanej rzeczywistości. Istotą funkcji jest tworzenie metafory, bycie elementem pomocniczym przenośni. Pozostałe funkcje wiążą się z przedmiotowym osadzeniem motywu w świecie przedstawionym utworu literackiego. Za najmniej istotną spośród pozostałych autor uznał funkcję dekoracyjną, gdyż występowanie motywów w tej funkcji jest bardzo rzadkie i czysto konwencjonalne. Są to elementy kompozycyjne całkowicie fakultatywne - ich obecność w literaturze ma charakter wyłącznie stylistyczny. Funkcję tę pełnią na przykład wszelkie wyliczenia lub wtrącenia, których nie tłumaczą żadne uzasadnienia. Funkcja mimetyczna polega natomiast na chęci przeniesienia świata realnego do fikcji literackiej. Motywy występujące w tej funkcji służą stworzeniu naturalnego tła wydarzeń, stanowiąc konsekwencję postawy naśladowania rzeczywistości, dostosowania świata empirycznego do tego, co literackie. Funkcja przedmiotowa dotyczy wykorzystania występujących obiektów przyrodniczych zgodnie z ich naturą i przeznaczeniem. Należą do niej korzyści wynikające z obcowania człowieka ze światem roślin, jak również zagrożenia wypływające z natury. Wykorzystanie obiektów przyrodniczych w celu wyrażenia nastrojów, emocji i wszelkich przeżyć wiąże się z funkcją ekspresywną. Jest ona w pewnym stopniu podobna do funkcji metaforycznej, ponieważ stanowi nośnik treści wewnętrznych i znak uczuć, jednak w odróżnieniu od funkcji metaforycznej motywy przyrodnicze występujące w funkcji ekspresywnej są składnikami świata przedstawionego. Za pośrednictwem emocjonalnego ujęcia elementów przyrody odbiorca wydobywa wiedzę i rekonstruuje właściwe dla danej epoki reakcje człowieka i jego stosunek wobec natury oraz poznaje język, którym wyrażano związek człowieka z naturą. Podczas gdy funkcja ekspresywna zakłada pozaintelektualny sposób odnoszenia się do przyrody, to funkcja symboliczna wykorzystuje motywy naturalne do tworzenia najgłębszych pokładów znaczeniowych i odwołuje się do ogólnokulturowego funkcjonowania i znaczenia symboliki roślinnej. Andrzej Stoff podkreśla, że funkcję symboliczną pełnią nie tylko zindywidualizowane przedstawienia, ale i ujęcia skonwencjonalizowane, zakrzepłe znaki kulturowe, za pośrednictwem których literatura interpretuje i waloryzuje świat [Stoff, 1997, s. 9-22].

${ }^{13}$ Analiza materiału językowego zhierarchizowana została według liczby występujących motywów w danej funkcji, gdyż jednym ze sposobów oceny stopnia znajomości i tym samym 
pojawia się w czternastu różnych kontekstach, co stanowi ponad 45\% wszystkich motywów. Kalina jako główny element świata przedstawionego prezentowana była przede wszystkim w utworach balladowych, miłosnych i zalotnych, najczęściej jako krzew rosnący zawsze w sąsiedztwie jaworu, na przykład: Kalina z jeworem rozstać sie nie może a jo sie rozstała, mój wsechmocny Boze [Gębik, 1952, s. 84] ${ }^{14}$ lub Rozstańże się, rozstań, kalinko, z jaworem; bom się rozestała $z$ kochaneczkiem moim [Kolberg, 1966, s. 273] ${ }^{15}$. Kalinę i jawor zestawiano na zasadzie kontrastu. Kalina należy bowiem do roślin niskich - osiaga co najwyżej cztery metry, natomiast jawor to drzewo wyjątkowo wysokie, które dorasta nawet do 40 m [Podbielkowski, 1989, s. 137-138, 154-155]. Ponadto według tradycji ludowej kalina to krzew żeński, w przeciwieństwie do jaworu, który należy do drzew o symbolice męskiej. Dodatkowo podania ludowe mówią o jaworze rosnącym na mogile chłopca rozdzielonego z dziewczyną przez matkę, podczas gdy kalina ma wyrastać przede wszystkim na grobach młodych dziewcząt [Szcześniak, 2013, s. 155-156, 198-199]. Kontekst kulturowy może wskazywać tym samym na symboliczne wykorzystanie motywu, według którego kalina byłaby tu uosobieniem kobiety, jawor zaś wyobrażeniem mężczyzny. Jednakże ze względu na brak właściwych przesłanek w tekście ludowym, które wskazywałyby na nadmieniony kierunek interpretacji, uznałam zakwalifikowanie owego motywu do funkcji mimetycznej (nie zaś symbolicznej) za bardziej zasadne.

Pieśni ludowe zestawiają kalinę i jawor również w kontekście porównania szerokości liści obu gatunków, jak w utworze: Przy dolinie wódka $<$ plynie $>$, szeroki list na kalinie; jeszcze szerszy na jaworze, pożalże się, mocny Boże! [Kolberg, 1966, s. 243] ${ }^{16}$. Liść stanowi tym samym główny wyznacznik cech

kulturowej ważności badanego wycinka pozajęzykowej rzeczywistości może być liczba opisujących go wyrazów, jak twierdzi Jolanta Maćkiewicz: „bogactwo słownictwa (i frazeologii) traktuje się bowiem zwykle jako przejaw zainteresowania daną sferą rzeczywistości” [Maćkiewicz, 1991, s. 183].

${ }^{14}$ Inne warianty tej pieśni: Kalina z jeworem rozstać sie nie moze [Sobieski, 1955, s. 95], Kälinkä z jeworem rozstäć sie nie może [Kolberg, 1966, s. 272], Kalinka z jaworem rozstać się nie może [Kolberg, 1966, s. 274], Kalinka w jeworem rozstać sie nie może, a ja sie rozstałam, mój wsechmocny Boze [Kętrzyński, 1988, s. 55], Kalinka z jeworem rozstać się nie może [Gizewiusz, 2000, s. 144], Kalina z jeworem rozstać sie nie moze [Krzyżaniak, Pawlak, 2002, III, s. 127].

${ }^{15}$ Inne warianty tej pieśni: Rozstańze sie, rozstań, kälinko, z jeworem [Kolberg, 1966, s. 272], Rozstańze sie, rozstań, kalino z jeworem [Kętrzyński, 1988, s. 55], Rozstańże się, rozstań kalinko z jeworem, bom się rozestała z kochaneczkiem moim [Gizewiusz, 2000, s. 144], Rozstań-ze się, rozstań kalinko z nieworym [Krzyżaniak, Pawlak, 2002, III, s. 183].

${ }^{16}$ Inne warianty tej pieśni: Szeroki list na kalinie jeszcze szerszy na jaworze [Oracki, 1957, s. 224], Széroki list na kalinie, jeszcze szerszy na jaworze [Kolberg, 1966, s. 243], Szeroki list na kalinie, jeszcze szerszy na jeworze [Kolberg, 1966, s. 527], Szeroki list na kalinie, jeszcze szerszy 
gatunkowych kaliny, która w tym kontekście przedstawiona została jako roślina o szerokich liściach, opisywanych przez botaników jako dłoniaste [Podbielkowski, 1989, s. 137-138].

Pieśni folklorystyczne często eksponują liście jako najbardziej reprezentatywną część rośliny. Według tekstów ludowych ten element krzewu występuje najczęściej na znacznej wysokości, np.: Wysoko, daleko listek na kalinie; kto się w kim zakocha, pewnie go nie minie [Kolberg, 1966, s. 519] ${ }^{17}$. Kalina jako krzew nie należy do roślin wysokich, dlatego najprawdopodobniej jest tu ona wysoko położona - rośnie na wzniesieniu. Inne pieśni wskazują natomiast, iż kalina występuje na niżu, w dolinie: Cemu kalinko w dole stois, cy sie na górze susy bois? Gdybym sie susy nie bojała, tobym w dołecku nie stojała [Kętrzyński, 1988 , s. 74$]^{18}$. Obraz ten, stanowiący konsekwencję postawy naśladowania rzeczywistości (właściwą funkcji mimetycznej), tworzy typowy wizerunek krzewu, który w Polsce „występuje w stanie dzikim w wilgotnych lasach i zaroślach” [Podbielkowski, 1989, s. 137-138].

Stworzeniu naturalnego krajobrazu w pieśniach ludowych służą również konteksty, w których kalina podlega typowym dla siebie stanom i procesom. Należy do nich grupa utworów, w których krzew prezentuje się w stadium pełni rozwoju, pokryty kwiatami: A na kalince śliczne kwiecie [Krzyżaniak, Pawlak, 2002, II, s. 63], zakwitający: Kalina zakście pięknie w ogrodzie, wtedy zotnierze stana w paradzie [Kolberg, 1966, s. 554] ${ }^{19}$, rozwijający się: Stójze, kalinko, rozwijaj sie, a ty, dziewcynko, rozmiślaj sie [Gąsiorowski, 1976, s. 32] ]20.

na jaworze [Gizewiusz, 2000, s. 149], Szeroki list na kalinie, jeszcze szerszy na jaworze [Gizewiusz, 2000, s. 202], Szeroki list na kalinie, jeszcze szerszy na jaworze [Gizewiusz, 2000, s. 203].

${ }^{17}$ Inne warianty pieśni: Wysoko, daleko listek na kalinie [Kolberg, 1966, s. 274], Wysoko, daleko listek na kalinie [Gizewiusz, 2000, s. 191], Szeroko, wysoko listek na kalinie [Gizewiusz, 2000, s. 192], Wysoko, daleko listek na kalinie [Gizewiusz, 2000, s. 284].

${ }^{18}$ Inne warianty pieśni: Czemu, kalinko, $w$ dole stoisz [Okęcka-Bromkowa, 1966, s. 41], Czemu, kalinko, $w$ dole stois [Kolberg, 1966, s. 127], Czemuż, kalinko, $w$ dole stoisz [Kolberg, 1966, s. 515], Cетu, kalinko, $w$ dole stojis [Gąsiorowski, 1976, s. 32], Czemuż, kalinko, $w$ dole stoisz [Gizewiusz, 2000, 205], Czego, kalinko, $w$ dole stoisz [Gizewiusz, 2000, s. 206], A tu, kalinko, $w$ dole stoisz [Gizewiusz, 2000, s. 207], A ty, kalinko, $w$ dole stoisz [Gizewiusz, 2000, s. 207], Ej ty, kalinko, $w$ dole stojysz [Krzyżaniak, Pawlak, 2002, II, 63], |:A ty, kalinko, $w$ dole stojisz:| [Krzyżaniak, Pawlak, 2002, II, s. 64], |:Cymuz, kalinko, w dole stojis:| [Krzyżaniak, Pawlak, 2002, II, s. 64], Cymu, kalinko, $w$ dole stojis [Krzyżaniak, Pawlak, 2002, II, s. 64], |:Cymuz, kalinko, $w$ dole stojisz:| [Krzyżaniak, Pawlak, 2002, II, s. 65].

${ }_{19}$ Inny wariant pieśni: Kalina zakście pięknie wogrodzie, tedy $<$ to wojsko > stanie w paradzie [Kolberg, 1966, s. 397].

${ }^{20}$ Inne warianty pieśni: Ej ty, kalinko, rozwijoj sie,|:ej ty, dziewczynko, rozmyśloj sie:| [Krzyżaniak, Pawlak, 2002, II, s. 63], |:A ty, kalinko, rozwijaj sia:|, |:a ty, dziyweczko, rozmyślaj sia:| [Krzyżaniak, Pawlak, 2002, II, s. 64], |:Ślicna kalinko, rozwijoj sie:||:a ty, dziewcynko, rozmyślaj 
W innych jeszcze utworach kalina przedstawiana jest u schyłku cyklu wegetacyjnego, gdy opadają z niej liście: Gunski moje, gunski, |:co byndzieta jadti:|, kedy już w kalince listeczki opadty [Krzyżaniak, Pawlak, 2002, III, s. 198]. Kolejny raz pieśn ludowa eksponuje liście jako najbardziej charakterystyczną część rośliny. Ich opadanie należy do naturalnych procesów, którym podlegają drzewa i krzewy liściaste w klimacie umiarkowanym (panującym w Polsce). Takie zarysowanie tła utworu wynika najwyraźniej z chęci przeniesienia świata realnego do fikcji poetyckiej, podobnie jak w pieśniach, w których kalina chwieje się/buja się/giba się: Stój więc, kalinko, nie chwiej się a ty, dzieweczko, namyślaj się [Okęcka-Bromkowa, 1966, s. 41], Stójże, kalinko, nie bujaj się, a ty, me dziewczę, rozmyślaj się [Kolberg, 1966, s. 515] $]^{21}$, A ty, kalinko, nie gibaj się, a ty, dziewczynko, rozmyślaj się [Gizewiusz, 2000, s. 207] ${ }^{22}$. Wizerunek ten odpowiada rzeczywistemu wyglądowi krzewu, który z natury jest delikatny i wiotki, a przez to narażony na uginanie się. Zestawienie w przywołanych fragmentach chylącej się kaliny z dziewczynąjest znamienne dla twórczości ludowej, w której gałązki krzewu chylące się ku ziemi symbolicznie wiązano z kobiecym smutkiem i niedolą.

Pieśni ludowe, w których nazwa krzewu pełni funkcję mimetyczną właściwă prezentują kalinę z jednej strony jako krzew występujący samotnie, tak jak we fragmencie: |: a tu kalina, biydna ptaszyna, samotna stoji, lato wspomina:| [Krzyżaniak, Pawlak, 2002, V, s. 140] ${ }^{23}$, z drugiej jako roślinę rosnącą w skupisku nazywanym kalinowym lasem, np.: W kalinowym lasku |:wzisi torba psiasku:| [Krzyżaniak, Pawlak, 2002, III, s. 144]. Ponadto utwór, w którym pod kaliną rosną grzyby, również może wskazywać na występowanie krzewu w skupisku leśnym: Kalina, kalina, pod kalina grzybki [Okęcka-Bromkowa, 1966, s. 324]. Świadczy to o dostosowywaniu świata empirycznego do fikcji wykreowanej w pieśni ludowej, gdyż, jak podają źródła botaniczne, miejscem występowania kaliny są najczęściej lasy.

sie:| [Krzyżaniak, Pawlak, 2002, II, s. 64], Rośnij, kalinko, rozwijaj sie,|:a ty, dziewcynko, rozmyślaj sie:| [Krzyżaniak, Pawlak, 2002, II, s. 64], |:A ty, kalinko, rozwijoj sie:|,|:a ty, dziewcyno, rozmyśloj sie:| [Krzyżaniak, Pawlak, 2002, II, s. 65].

${ }^{21}$ Inny wariant pieśni: Stojże, kalinko, nie bujaj się, a ty, me dziewczę, rozmyślaj się [Gizewiusz, 2000, s. 206].

${ }^{22}$ Inne warianty pieśni: A ty, kalinko, nie gibaj się, sliczna dziewczyno, rozmyślaj się [Gizewiusz, 2000, s. 206], A ty, k[alinko], nie gibaj się, a ty, dziewczyno, rozmyślaj się [Gizewiusz, 2000, s. 207].

${ }^{23}$ Inny wariant pieśni: |: a tu kalina, biedna ptaszyna, samotna stoji, lato wspomina:| [Krzyżaniak, Pawlak, 2002, V, s. 140]. 
Realizacja motywu kaliny w funkcji mimetycznej relacyjnej, w której nazwa gatunku rośliny, oprócz tworzenia naturalnej scenerii, stanowi jednocześnie miejsce działań bohaterów, pojawia się w dziesięciu kontekstach, co przekłada się na około $30 \%$ wszystkich użyć nazwy w pieśniach ludowych. Kalina, stojąc w relacji wobec ludzi i zwierząt, prezentuje się najczęściej jako miejsce schronienia, w którym bezpieczny spoczynek odnajduje młoda kobieta: Nadobna dzieweczka we świat wędrowała, w kalinowym lesie pierwsza nocke spała [Oracki, 1957, s. 235] ${ }^{24}$ lub ukrywa się ptak: Tam koło mina rosła kalina, a w niyj ukryta biła ptaszina [Krzyżaniak, Pawlak, 2002, V, s. 140] ${ }^{25}$. Kalinowy las/kalina jawi się w tej perspektywie jako miejsce bezpieczne, w którym schronienie może znaleźć zarówno człowiek, jak i zwierzę. Takie traktowanie krzewu ma swoje źródło w mitologii słowiańskiej. W świetle przekazów była to roślina święta, nietykalna, niezagrożona nawet uderzeniami piorunów, dlatego wierzono, że w kalinie można było znaleźć bezpieczne schronienie podczas burzy.

Pozytywne konotacje łączone z omawianym gatunkiem odzwierciedlają również utwory, w których kalinowy las stanowi miejsce radosnych spotkań młodych dziewcząt: Poszły panny w kaliny, Jasiuleczek za niemi [Kolberg, 1966, s. 126] ${ }^{26}$, miłych rozmów: Tam ci, tam ci w kalinowym lasku słowko sobie

${ }^{24}$ Inne warianty tej pieśni: Nadobna dzieweczka w świat odwędrowała, w kalinowym lasku pierwsza nockę spała [Oracki, 1957, s. 213], Nadobna dziewczyna we świat wędrowała, w kalinowym lesie nocke przespała [Okęcka-Bromkowa, 1966, s. 384], Nie taka dziewczyna śwata wandrowała, w kalinowym lasku psiérszo nocka spała [Steffen, 1931, s. 87], Nadobna dzieweczka w'świat odwędrowała; w kalinowym lesie pierwsza nocke spała [Kolberg, 1966, s. 267], Nadobne dziewczatka precz powędrowaty, w kalinowym lasku pierwsza nockę <spały> [Kolberg, 1966, s. 267], W kälinkowym lasku nockie nocowäłä, jesce nie świtäto, o przewóz wołała [Kolberg, 1966, s. 269], Nadobna dzieweczka $w$ świat odwędrowała; $w$ kalinowym lesie pierwsza nocke spała [Kolberg, 1966, s. 425], Nadobna dziewcyna, gdy w świat wędrowała, w kalinowym lasku pjerszą nocke spała [Gąsiorowski, 1976, s. 132], W kalinkowym lasku nockie nocowała, jesce nie switało, o przewoz wołała [Kętrzyński, 1988, s. 55], Nadobne dziewczątka precz powędrowały, |:w kalinowym lasku pierwsza nocke spali :| [Gizewiusz, 2000, s. 247], Nadobne dziewczatka precz powędrowaty, w kalinowym lasku pierwsza nockę spali [Gizewiusz, 2000, s. 273], Nadobna dzieweczka w swiat odwędrowała, w kalinowym lesie pierwsza nockę spała [Gizewiusz, 2000, s. 285], Nadobna dziywc-ina | we śwat wyndrowała, w kalinowym lasku | psiyrsó nocke spała [Krzyżaniak, Pawlak, 2002, II, s. 84], Kalyckie dziywczoki |we śwat wandrowati:|, w kalinowym losku |:piyrszo nocka mniati:| [Krzyżaniak, Pawlak 2002, II, 85], Nadobno dziwcyna we śwat wyndrowała, w galilowym losku psiyrwsó nocke spała [Krzyżaniak, Pawlak, 2002, II, s. 85].

${ }^{25}$ Inny wariant tej pieśni: |:a tu kalina, biedna ptaszyna, samotna stoji, lato wspomina: [Krzyżaniak, Pawlak, 2002, V, s. 140].

${ }^{26}$ Inne warianty tej pieśni: Poszly panny w kaliny [Gizewiusz, 2000, s. 118], Poszly panny w kaliny [Gizewiusz, 2000, s. 118], Poszły panny w kaliny [Gizewiusz, 2000, s. 119]. 
mówity [Kolberg, 1966, s. 126] ${ }^{27}$ oraz wspólnego wicia wianków: Zija zionki, Jasieczku, w kalinowym laseczku [Steffen, 1931, s. 49]. Kalinowy las kojarzony bywa $\mathrm{z}$ radosną atmosferą również w pieśniach, w których stanowi on miejsce przebywania i śpiewu ptaków: A w tym lasecku kalinowym tam ci ptasecek śpchiewa [Gąsiorowski, 1976, s. 100] czy: W kialinoskiym lesie |:kukaweczka kuka:| [Krzyżaniak, Pawlak, 2002, II, s. 86].

W innym utworze skupisko kalin przedstawione zostało natomiast jako miejsce ciemne i ponure, stwarzające zatem poczucie zagrożenia: $W$ lesie ciemnym, kalinowym tam zabity krakowiaczek młody [Okęcka-Bromkowa, 1966, s. 389]. W przytoczonym fragmencie kalinowy las jest jednocześnie miejscem śmierci i pochówku młodego mężczyzny. W przedstawionej sytuacji znajduje wyraz zwyczaj sadzenia kaliny na grobach młodych ludzi, wywodzący się z epoki romantyzmu, który miał służyć informowaniu przechodniów o czystości duszy zmarłego.

Ponadto kalinowy las jako miejsce niebezpieczne przedstawiony został w utworze, w którym mężczyzna zachęca kobietę przebywającą w lesie po zmroku, do odbycia z nim aktu seksualnego: Wszystkie poginyli [gwiazdy],|:tylko jena świyci:|, w kalinowym losku, |:Jasiek Kaśka miynczy:| [Krzyżaniak, Pawlak, 2002, II, s. 85]. Tym samym kaliny bywają w pieśniach ludowych nie tylko ważnym elementem warmińsko-mazurskiego krajobrazu, ale również miejscem ludzkich działań, nawet tych występnych.

Przykładem budzącym wątpliwości klasyfikacyjne jest utwór poruszający znany ludowy motyw zbrodni dokonanej przez jedną z rywalizujących sióstr podczas zbierania malin: A na starszej brwi była kropla krwi. Z jakiej, z jakiej to przyczyny? Czy z maliny? Czy z kaliny? Boć to nie krew [Okęcka-Bromkowa, 1966, s. 365 $]^{28}$. Sok z owoców kaliny mógł pozostawić ślad na twarzy bohaterki, co najprawdopodobniej wiązało się ze zbieraniem jagód, a ta okoliczność wskazywałaby na użycie nazwy botanicznej w funkcji przedmiotowej. Jednakże ze względu na brak w utworze jednoznacznego wskazania na zbieranie kalin przez

${ }^{27}$ Inne warianty pieśni: Tam ci, tam ci w kalinowym lasku słowko sobie mowity [Gizewiusz, 2000, s. 118], Tam ci, tam ci w kalinowym lasku stówko sobie mowity [Gizewiusz, 2000, s. 118], Tam ci, tam ci w kalinowym lasku słowko do sie mowili [Gizewiusz, 2000, s. 119].

${ }^{28}$ Inne warianty pieśni: Na jej carnej brwi nibi kropla krwi; kto wji, z jakij to przicyny, od maliny lub kaliny. Moze to nie krew? [Gąsiorowski, 1976, s. 29], A na carnej brwi |jest kropelka krwi, |:cy z maliny, cy z kaliny, sam nie wiem, z jakiej przycyny, moze to nie krew:| [Krzyżaniak, Pawlak, 2002, II, s. 74], Na jej carnej brwi | biła kropla krwi, |:kto wie, z jakiej to prszycini, | "od maliny lub kaliny, może-ć to nie krew:| [Krzyżaniak, Pawlak, 2002, II, s. 75], Na jej czarnej brwi | niby kropla krwi, chtóż wie, z jakiej to przyczyny, | czy kaliny, czy maliny, może to nie krew:| [Krzyżaniak, Pawlak, 2002, II, s. 75]. 
bohaterki, przyjmuję, iż nazwa botaniczna wykorzystana została w funkcji mimetycznej relacyjnej. Kalina wpływa tu bowiem na wizerunek człowieka, stojąc wobec niego w pewnej relacji.

Funkcja przedmiotowa, która dotyczy wykorzystywania konkretnych obiektów przyrodniczych zgodnie $\mathrm{z}$ ich naturą i przeznaczeniem, pojawia się w trzech różnych kontekstach, stanowiąc niecałe $10 \%$ wszystkich motywów z udziałem kaliny. Użyteczność omawianego krzewu wiąże się przede wszystkim ze spożywaniem jego owoców, czego potwierdzeniem jest fragment pieśni: Lubiem kaliny krasne jagódki [Krzyżaniak, Pawlak, 2002, V, s. 140] ${ }^{29}$, w której bohater chwali smak kalinowych jagód, zwracając dodatkowo uwagę na ich czerwoną barwę. Działania człowieka związane z wykorzystaniem rośliny dla własnych potrzeb i korzyści dotyczą również kontekstów, w których kalina pełni rolę surowca, z którego wykonany został wieniec: Siedzi jescur w toncu, | w kalinowym wioncu [Krzyżaniak, Pawlak, 2002, IV, s. 233]. Przywołany utwór jest rodzajem przyśpiewki wykonywanej podczas zabawy „Siedzi jescur w tańcu”, a kalinowy wieniec pełni w tym kontekście rolę umownego rekwizytu ${ }^{30}$.

Jak konstatuje Andrzej Stoff, do funkcji przedmiotowej należą motywy mówiące o korzyściach wynikających z obcowania człowieka ze światem roślin, jak również o zagrożeniach wypływających z natury. Ze względu na specyfikę badanego materiału należy dodać do tego również konteksty, w których to człowiek, w wyniku świadomego działania, naraża przyrodę na zniszczenie, tak jak to przedstawiono w utworze: Na tej górze mogiła, stojała tam dziewczyna; ćwierć kaliny tamała, na kozaka kiwała [Kolberg, 1966, s. 556] ${ }^{31}$. W świetle przytoczonych wcześniej informacji etnograficznych łamanie gałęzi kaliny jest czynem znamiennym, gdyż według ludowych wierzeń miało ono skutkować nieszczęściem.

Kolejne miejsce pod względem frekwencji występowania zajmuje funkcja symboliczna, która w odniesieniu do nazwy kalina zastosowana została w trzech pieśniach należących do grupy utworów miłosnych, przekładając się zaledwie

${ }^{29}$ Inny wariant pieśni: Lubiem kaliny krasne jagódki [Krzyżaniak, Pawlak, 2002, V, s. 140].

${ }^{30}$ Uczestnicy zabawy formowali koło, trzymając się za ręce. Jedna osoba, siedząca w środku na krześle, zbierała fanty. Podczas wykonywania pieśni chłopcy i dziewczęta biorący udział w zabawie przesuwali się w kole zgodnie z ruchem wskazówek zegara, a podczas wypowiedzenia ostatniej frazy utworu $D a c ́ m u$, dać, osoba znajdująca się na wprost ,jaszczura” musiała oddać fant. Zabawa kończyła się, kiedy każdy z uczestników zabawy oddał przynajmniej jedną rzecz, którą następnie należało wykupić, wykonując powierzone przez „sędziego” zadanie [Krzyżaniak, Pawlak, 2002, IV, s. 233].

${ }^{31}$ Inny wariant pieśni: Na tej gorze mogiła, stojała tam dziewczyna, ćwierć kaliny tamała, na kozaka kiwała [Gizewiusz, 2000, s. 336]. 
na około 8\% ogółu kontekstów. Funkcja symboliczna wykorzystuje motywy naturalne do tworzenia najgłębszych pokładów znaczeniowych i odwołuje się do ogólnokulturowego funkcjonowania i znaczenia symboliki roślinnej. Andrzej Stoff podkreśla, że funkcję symboliczną pełnią nie tylko zindywidualizowane przedstawienia, ale i ujęcia skonwencjonalizowane, zakrzepłe znaki kulturowe, za których pośrednictwem literatura interpretuje i waloryzuje świat. Przykładem wykorzystania badanego motywu w tej funkcji są pieśni odnoszące się do utrwalonego w kulturze ludowej znaczenia kaliny jako symbolu kobiety, na przykład: Pódziem, kalinko, zas w ciemny las, zaspiewać nam tam słowiczek nasz [Gizewiusz, 2000, s. 207]. Za wykorzystaniem nazwy w funkcji symbolicznej przemawia kontekst utworu, który skonstruowany został na zasadzie dialogu mężczyzny z kobietą. Bohater zwraca się do swej rozmówczyni początkowo dziewczyno, po czym w końcowej partii utworu zamienia to sformułowanie na zwrot kalino, co wskazuje na równoznaczne potraktowanie określeń kalina i dziewczyna. Jest to odniesienie do utrwalonej w kulturze wartości krzewu, który często porównywano w pieśniach ludowych do młodej kobiety. Najczęściej do kaliny przyrównywana była dziewczyna zakochana, natomiast jeśli była ona biedna lub samotna, porównywano ją do kaliny, która nie zakwita ${ }^{32}$. Posłużenie się nazwą gatunku rośliny w odniesieniu do kobiety występuje również w pieśni, w której oba określenia zostały zestawione na zasadzie gradacji: Kalina malina, dziewczyna kochano, powiadajo ludzie, żeś ty malowano. Kalina malina, dziewczyna kochano, powiedajo ludzie, żeś ty malowano [Krzyżaniak, Pawlak, 2002, III, s. 95].

W innym utworze realizującym symboliczny wymiar kaliny krzew ten, odczytując tekst w sposób dosłowny, stanowi tworzywo budulcowe mostu: $E j$, uginaj się, ej, uchylaj się, kalinowy moście [Okęcka-Bromkowa, 1966, s. 42]. Biorąc natomiast pod uwagę kontekst kulturowy, klasyfikacja użycia leksemu okazuje się zbliżać wykorzystanie motywu do funkcji symbolicznej. Kalinowy most posiada bowiem bardzo rozbudowaną symbolikę - przede wszystkim $\mathrm{w}$ folklorze rosyjskim i białoruskim. Most wykonany z drewna kalinowego w pieśniach ludowych Słowian Wschodnich miał znaczenie przejścia miedzy granicznej, przy czym pierwotnie była to granica między doczesnością a światem zmarłych. W późniejszych czasach obiekt ten symbolizował zapowiedź zmiany stanu - przejścia młodej dziewczyny do grona mężatek, a w konsekwencji łączono go z drogą nowożeńców, jaką przemierzali z domu panny młodej do

${ }^{32}$ Pochodzenie kaliny wiązano również z kobietą, która zginęła - w wyniku zaklęcia bądź z powodu nieszczęśliwej miłości. Niekiedy kalinę i jej gorzkie owoce interpretowano także jako symbol kobiety znajdującej się w stanie przejścia (zmiany statusu społecznego z panny na mężatkę) lub młodej, niekochanej żony i jej gorzkiego życia [Szcześniak, 2015, s. 155-166]. 
gospodarstwa jej wybranka [Szcześniak, 2013, s. 195]. Kontekst utworu w tym przypadku jednoznacznie wskazuje na ten kierunek interpretacji - bohaterka przywoływanej pieśni, znajdując się na kalinowym moście, stara się nawiązać z tego miejsca kontakt z nieżyjącym rodzicami, których zaprasza na swój ślub.

Najmniejszą liczbę użyć posiada funkcja dekoracyjna, która wykorzystana została zaledwie w dwóch tekstach folklorystycznych, należących do pieśni o tematyce żołnierskiej. Andrzej Stoff uznaje tę funkcję za najmniej istotną, gdyż występowanie analogicznych motywów jest bardzo rzadkie i ma czysto konwencjonalny charakter. Są to elementy kompozycyjne całkowicie fakultatywne - ich obecność w literaturze ma charakter wyłącznie stylistyczny. Funkcję tę pełnią na przykład wszelkie wyliczenia lub wtrącenia, których nie da się uzasadnić, tak jak w pieśniach: Siedem koni Jasio miat, wszystkie rano osiadłał, kalinka moja. Jak na mostek wyjeżdzaty, wszystkie na raz zarżaty, kalinka moja [...] [Okęcka-Bromkowa, 1966, s. 140-141] $]^{33}$ oraz Siytym kóni Jasio mniat, | wszystkie siytym obsiodtat, kalina, kalina, kalina moja, | wszystkie siytym obsiodtat. Jak na mostek wpadali, | ws-iscy siytym zarżeli, kalina, kalina, kalina moja, | ws-iscy siytym zarżeli [...] [Krzyżaniak, Pawlak, 2002, II, s. 219] ${ }^{34}$.

\section{PODSUMOWANIE}

W świetle przywołanych przykładów i przeprowadzonej analizy można zaobserwować zależność zachodzącą między znaczeniem nazwy roślinnej a funkcją, w jakiej została ona wykorzystana. Funkcja mimetyczna dotyczy niemal wyłącznie fitonimów w znaczeniu czysto roślinnym, odstępstwo od tej reguły w przypadku kaliny dotyczy niejednoznacznej do rozstrzygnięcia kwestii kwitnięcia/ rozwijania się, które może obejmować zarówno całą roślinę, jak i jej poszczególne części. Podobne wnioski wynikają $\mathrm{z}$ analizy motywów w funkcji mimetycznej relacyjnej, która w głównej mierze odnosi się do nazw botanicznych w znaczeniu

${ }^{33}$ Dalsza część utworu: Konie moje, nie rżyjcie, napasę was dziś w życie, kalinka moja. W zimnym zdroju napoję, sam się pięknie ustroję, kalinka moja. I usiadę pod kwitnaca wiśnia, będę sobie cicho rozmyślat, kalinka moja. Żem dziewczynę zdradził nieładnie, krzywda jej na me serce upadnie, kalinka moja [Okęcka-Bromkowa, 1966, s. 140-141].

${ }^{34}$ Dalsza część utworu: Wy, kóniki, nie rżyjcie, | ze napase was w zycie, kalina, kalina, kalina moja, | ze napase was w zycie. W zimnym zdrojo napoje, | sam się póde ustroje, kalina, kalina, kalina moja, | sam się póde ustroje. I usiunde pod wiśnió, | i tak sobie rozmyślut, kalina, kalina, kalina moja, | i tak sobie rozmyślut. I tak sobie rozmyślut, | chtórnó panne zdradzić miat, kalina, kalina, kalina moja, | chtórnó panne zdradzić miat. Zdradziułym jó nieładnie, | oj, chtóż teraz "ogarnie, kalina, kalina, kalina moja, | oj, chtóż teraz "ogarnie. Nie ogarnie ojciec, mać, | ze musiałem sam jó brać, kalina, kalina, kalina moja, | ze musiałem sam jó brać. [Krzyżaniak, Pawlak, 2002, II, s. 219]. 
czysto roślinnym, z wyjątkiem budzącego wątpliwości przykładu, w którym kalina - pozostawiając ślad na czole kobiety, będący najprawdopodobniej wynikiem zrywania jagód - potencjalnie powinna przyjąć funkcję przedmiotową. Jednakże ze względu na brak bezpośredniego wskazania okoliczności pojawienia się znamienia, uznałam dla tego przypadku funkcję mimetyczną relacyjną. Funkcja przedmiotowa, dotyczącą wykorzystania rośliny przez człowieka w celach praktycznych, związana jest zawsze ze znaczeniem genetycznym oraz partytywnym. Człowiek używa bowiem zazwyczaj poszczególnych elementów rośliny bądź surowców z niej pochodzących. Jednak i w tym wypadku wśród pieśni ludowych pojawia się wyjątek: mowa w nim o kalinowych jagodach, gdzie leksem kalina, mimo iż pojawia się w znaczeniu czysto roślinnym, dotyczy części rośliny, jaką jest owoc. Funkcja symboliczna w przypadku motywu kaliny związana jest wyłącznie ze znaczeniem czysto roślinnym, co nie stanowi jednak reguły, lecz jest uwarukowane kulturową wartością danego gatunku - jednostkowym sposobem tworzenia symboli. Natomiast funkcja dekoracyjna zawsze łączy się ze znaczeniem czysto roślinnym, ponieważ wykorzystanie w tym kontekście nazwy rośliny ma wyłącznie charakter stylistyczny. Fitonim, który jest pozbawiony wartości semantycznej, nie może zatem wykazywać modyfikacji znaczenia.

Analiza funkcjonalno-znaczeniowa wykazała ponadto, że wizerunek kaliny wykorzystany został w pieśniach ludowych przede wszystkim w celu stworzenia naturalnego tła wydarzeń, co przejawia się w dominacji funkcji mimetycznej. Kalina w podobnych kontekstach stanowi charakterystyczny element krajobrazu - rośnie we wskazanych miejscach (wzniesienie lub dolina) i w określonym sąsiedztwie (w skupisku, samotnie lub w towarzystwie jaworu) oraz podlega typowym dla rośliny stanom i procesom (zakwita, więdnie, ugina się). Utwory takiego rodzaju eksponują jednocześnie podstawowe właściwości rośliny: niewielki rozmiar, wiotkość, szerokość liści.

Opisywany fitonim, pełniąc funkcję mimetyczną, występuje jednocześnie w roli obiektu wchodzącego w pewne relacje z bohaterami pieśni ludowych. Dotyczy to przede wszystkim funkcji mimetycznej relacyjnej, w której kalina stanowi miejsce działań ludzi bądź zwierząt. Analizowany gatunek rośliny przedstawiony jest $w$ tych kontekstach przede wszystkim jako miejsce schronienia człowieka i zwierząt, spotkań młodych dziewcząt czy ptasich śpiewów Jednocześnie kalinowy las przedstawiany bywa jako miejsce zbrodni i pochówku, i tym samym tworzy ambiwalentny wizerunek rośliny, która może być zarówno miejscem bezpiecznym i radosnym, jak i przestrzenią, w której panuje atmosfera zagrożenia. Pieśni folklorystyczne realizują także utrwalone w kulturze ludowej 
wyobrażenie kaliny jako drzewa bezpiecznego od uderzeń piorunów oraz przywołują zwyczaj sadzenia kaliny na grobach młodych ludzi.

Bliską zależność panującą między człowiekiem a rośliną prezentuje również funkcja przedmiotowa, w której krzew wykorzystywany jest w celach praktycznych. Człowiek w tych kontekstach spożywa owoce kaliny, wykonuje wianki z kwiatów oraz buduje mosty z kalinowego drewna, ale również działa na szkodę rośliny, łamiąc jej gałęzie. Pieśni te eksponują czerwień jagód jako cechę gatunkową kaliny oraz nawiązują do tradycyjnego znaczenia kalinowego mostu jako symbolu przejścia.

Utwory, w których wykorzystano nazwę botaniczną w funkcji symbolicznej, realizują ugruntowany w tradycji ludowej obraz kaliny jako symbolu kobiecości. Użycie nazwy gatunku krzewu jako synonimu kobiety świadczy o głębokim zakorzenieniu wizerunku rośliny w świadomości mieszkańców regionu. Silną pozycję, jaką zajmuje omawiany gatunek w mentalności mieszkańców Warmii i Mazur, potwierdzają ponadto liczne użycia fitonimu w funkcji dekoracyjnej. Warto również podkreślić, że kalina to jeden z nielicznych gatunków krzewów, któremu Warmiacy i Mazurzy poświęcili tak wiele miejsca w pieśniach ludowych, co skutkuje swoistą nobilitacją rośliny i świadczy o wyjątkowym miejscu, jakie zajmowała ona w życiu i kulturze omawianego regionu.

\section{BIBLIOGRAFIA}

BAGIŃSKI Stefan, Mowszowicz Jakub, 1963, Krajowe rośliny trujące, Państwowe Wydawnictwo Naukowe, Łódź.

BASARA Anna, 1987, Charakterystyka fonetyczna gwar Ostródzkiego, Warmii i Mazur wedtug stanu z poczatku lat pięćdziesiatych, w: Z. Stamirowska, red., Stownik gwar Ostródzkiego, Warmii i Mazur. T. 1. A-Ć, Wydawnictwo Instytutu Języka Polskiego Polskiej Akademii Nauk, Wrocław, s. 24-31.

Bıolik Maria, 2014, Dialekt warmiński: fonetyka i fonologia, Wydawnictwo Uniwersytetu Warmińsko-Mazurskiego, Olsztyn.

CzIKow Paweł, ŁaPTIEW Jerzy, 1982, Rośliny lecznicze i bogate $w$ witaminy, Państwowe Wydawnictwo Rolnicze i Leśne, Warszawa.

Doroszewski Witold, red., 1964, Stownik języka polskiego, t. III, Wydawnictwo Naukowe PWN, Warszawa.

DrabiK Lidia, Sobol Elżbieta, red., 2007, Stownik języka polskiego PWN, t. II, Wydawnictwo Naukowe PWN, Warszawa.

DuBISz Stanisław, 1977, Nazwy roślin w gwarach ostródzko-warmińsko-mazurskich, Zakład Narodowy im. Ossolińskich, Wrocław. 
Gąsiorowski Józef, 1976, Stoi lipa, lipuleczka. Pieśni mazurskie przez Józefa Gąsiorowskiego w 1884 roku zebrane, Ludowa Spółdzielnia Wydawnicza, Warszawa.

GĘBIK Władysław, oprac., 1952, Pieśni ludowe Mazur i Warmii, Wydział Kultury Prezydium Wojewódzkiej Rady Narodowej, Olsztyn.

Gizewiusz Gustaw, 2000, Pieśni ludu znad Górnej Drwęcy w parafiach ostródzkiej i kraplewskiej zbierane od 1836 do 1840 roku, Instytut im. Oskara Kolberga, Poznań.

KĘTRZYŃSKi Wojciech, 1988, O Mazurach, Wydawnictwo Pojezierze, Olsztyn. Kolberg Oskar, 1966, Dzieła wszystkie, t. 40: Mazury Pruskie, Ludowa Spółdzielnia Wydawnicza, Wrocław.

Krzyżaniak Barbara, Pawlak Aleksander, 2002, Warmia i Mazury, część I-V, Instytut Sztuki PAN, Warszawa.

MaĆKIEWICZ Jolanta, 1991, Czy istnieja językowe wyznaczniki kultury morskiej?, w: J. Anusiewicz, J. Bartmiński, red., Język a kultura. T. 1: Podstawowe pojęcia i problemy, Wiedza o Kulturze, Wrocław, s. 181-189.

NiebrZEGowska Stanisława, 2000, Przestrach od przestrachu: rośliny w ludowych przekazach ustnych, Wydawnictwo Uniwersytetu Marii Curie-Skłodowskiej, Lublin.

Оке̨ска-Bromкоwa Maria, 1966, Śpiewa wiatr od jezior, Ludowa Spółdzielnia Wydawnicza, Warszawa.

ORACKI Tadeusz, oprac., 1957, Poezja ludowa Warmii i Mazur, PAX, Warszawa. Podbielkowski Zbigniew, 1989, Stownik roślin użytkowych: polski, taciński, angielski, francuski, niemiecki, rosyjski, Państwowe Wydawnictwo Rolnicze i Leśne, Warszawa.

Rовотүскі Czesław, BАвік Wiesław, red., 2005, Układ gniazdowy terminów i stownik stów kluczowych wybranych kategorii kultury. Medycyna ludowa, Wydawnictwo Uniwersytetu Jagiellońskiego, Kraków.

Rogowska-CyBulska Ewa, 2005, Aktywność nominacyjna nazw roślin w gwarze wagowskiej, w: taż, Gwarowy obraz roślin w świetle aktywności nominacyjnej ich nazw (na podstawie gwary wsi Wagi w powiecie łomżyńskim), Wydawnictwo Uniwersytetu Gdańskiego, Gdańsk, s. 83-122.

RumińsKa Antonina, OżARowski Aleksander, red., 1990, Leksykon roślin leczniczych, Państwowe Wydawnictwo Rolnicze i Leśne, Warszawa.

SobIESki Marian, oprac., 1955, Pieśni ludowe Warmii i Mazur, Polskie Wydawnictwo Muzyczne, Kraków.

StefFen August, 1931, Zbiór polskich pieśni ludowych z Warmji, Towarzystwo Pomocy Dzieciom i Młodzieży Polskiej w Niemczech, Poznań. 
SтоғF Andrzej, 1997, Problematyka teoretyczna funkcjonowania motywów roślinnych w utworach literackich, w: A. Martuszewska, red., Literacka symbolika roślin, Wydawnictwo Uniwersytetu Gdańskiego, Gdańsk, s. 9-22.

SzCZEŚNIAK Krystyna, 2013, Świat roślin światem ludzi na pograniczu wschodniej i zachodniej słowiańszczyzny, Wydawnictwo Uniwersytetu Gdańskiego, Gdańsk.

SzCZeŚNIAK Krystyna, 2015, Kalina oczyma slawisty etnolingwisty, w: P. Stalmaszczyk, I. Jaros, red., Amor verborum nos unit. Studia poświęcone pamięci Profesora Stawomira Gali, Wydawnictwo Uniwersytetu Łódzkiego, Łódź.

Trąba Czesława, Wolański Paweł, Rogut Krzysztof, 2014, Studium etnobotaniczne: znaczenie roślin w kulturze, tradycji i życiu człowieka, Stowarzyszenie na Rzecz Rozwoju i Promocji Podkarpacia Pro Carpathia, Rzeszów.

WeŁPa Agnieszka, 2014, Językowe komunikowanie uczuć w pieśniach ludowych z Warmii i Mazur, Wydawnictwo LIBRON - Filip Lohner, Kraków.

Zientara-Malewska Maria, 1959, Warmio moja miła, Instytut Wydawniczy PAX, Warszawa.

ZióŁKowska Maria, 1983, Gawędy o drzewach, Ludowa Spółdzielnia Wydawnicza, Warszawa.

Ewelina Lechocka

\section{ZNACZENIE I FUNKCJA MOTYWU KALINY W WARMIŃSKO- MAZURSKICH PIEŚNIACH LUDOWYCH}

Streszczenie

Artykuł prezentuje analizę motywu kaliny w antologiach warmińsko-mazurskich pieśni ludowych zebranych w XIX i XX wieku. Celem niniejszych badań było określenie funkcji słownictwa botanicznego $\mathrm{w}$ tekstach folklorystycznych oraz zestawienie poetyckiej reprezentacji motywu kaliny z jej rolą w życiu i kulturze mieszkańców Warmii i Mazur. Jak wynika z przeprowadzonej analizy, motyw kaliny wykorzystany jest w pieśniach w różnorodnych funkcjach: mimetycznej, przedmiotowej, symbolicznej i dekoracyjnej, co powoduje, że twórczość ludowa i funkcjonujące w niej wątki botaniczne stanowią niezwykle cenne źródło informacji o tożsamości ludności wiejskiej pochodzącej z terenów Warmii i Mazur. Wykorzystanie motywu kaliny w pieśniach charakteryzuje się bowiem znacznym podobieństwem do rzeczywistości empirycznej, w której roślina ta odgrywa dużą rolę zarówno w życiu codziennym, jak i w kulturze niematerialnej. 


\section{MEANING AND FUNCTION OF VIBURNUM MOTIVES IN FOLK SONGS FROM WARMIA AND MASURIA}

\section{Summary}

This article is an analysis of viburnum motives, which occurred in collection of Warmian and Masurian folk songs elaborated in XIX and XX century. The purpose of this study was to define meaning and function botanic vocabulary mentioned in folkloristic texts and to compare poetic representation of viburnum motif with its role in every-day-life and culture of Warmia and Masuria's inhabitants. As it was from maintained analysis, motives of viburnum is used in songs of various functions: mimetic, object, symbolic and decorative, which means that the folk output and botanic themes are a valuable source of information about identity of rural population from Warmia and Masuria territories. Utilization of viburnum motif in folksongs is characteristic for its strong resemblance to empiric reality, in which the plant plays a great role in every-day-life and in immaterial culture. 